\title{
THE RELATIONSHIP BETWEEN EDUCATION, JOB SATISFACTION, AND WORK MOTIVATION TO WORK PRODUCTIVITY (INVESTIGATION ON WORKERS IN THE WELDING SECTION OF RACK PRODUCTION AT UD. KING RACK, SURABAYA, INDONESIA)
}

\author{
Ni'matul Mawaddah' ${ }^{1}$, Indriati Paskarini ${ }^{1}$ \\ ${ }^{21}$ Department Of Occupational Health and Safety, \\ Faculty of Public Health, Airlangga University, Surabaya, Indonesia \\ Corresponding Author :Ni'matul Mawaddah \\ E-mail : nimatul.mawaddah-2015@fkm.unair.ac.id
}

\begin{abstract}
UD. King Rack Surabaya is a rack production home industry. The production process includes welding of the rack structure. This study aims to analyze the relationship between education, job satisfaction, and work motivation to the work productivity of workers in the welding section of rack production at UD. King Rack, Surabaya, Indonesia. This is an observational study with a cross-sectional design. The study sample used a total population of 12 workers. Data were taken in the form of primary data tested with the Spearman correlation test. The results of the analysis show that the majority of respondents graduated from elementary school and the majority of respondents' job satisfaction was high. However, majority of respondents' work motivation was moderate and the majority of respondents' work productivity was low. The results of the Spearman correlation analysis indicate a relationship between education and work productivity (correlation coefficient $=0.475$ ) as well as work motivation and work productivity (coefficient correlation $=1.000$ ). There was no relationship between job satisfaction and work productivity. To increase work productivity, daily standards for the number of racks to be produced by workers need to be set. Besides that, it is important to give praise and appreciation to the workers in order for them to produce racks that are above the work standard.
\end{abstract}

Keywords: education, job satisfaction, work motivation, work productivity

\section{INTRODUCTION}

Work productivity is the main driver of growth after a country reaches the available labor and capital limits (Asian Development Bank, 2018). According to the Asian Development Bank (2018), there are 180 million working-age people in 2015 and this will continue to increase to 250 million in 2035 based on the projection of the Central Statistics Agency. However, an increase in the number of workers does not guarantee an increase in work productivity. The informal sector in particular tend to have low productivity based on data from the Central Statistical Agency and National Labor Force Survey. This is due to low education and productivity qualifications. Informal sector workers have on average 8 years of schooling (Asian Development Bank, 2018).

Growth and development of work productivity can be done through effective and efficient use of resources. According to
Sedarmayanti (2011), increased work productivity depends on the abilities and attitudes of individuals at work as well as management and work organizations. Increased productivity is achieved by recognizing and planning for factors that affect work productivity. These factors are measured to determine the dominant factors related to work productivity.

Satisfaction toward working conditions, rewards, and cooperation between workers can increase work productivity (Sutrisno, 2010). Workers have different desires, needs, expectations, attitudes, and work experiences with each other that might influence work relations; this is work motivation. This can affect the attitude of workers to carry out work and work productivity (Sedarmayanti, 2011).

According to Sunyoto (2012), factors of knowledge, ability, attitude, behavior, and skill can affect work productivity. Sastrohadiwiryo (2005) also mentioned that about $80-90 \%$ of workers' 
performance depends on work motivation and about 10 - $20 \%$ depends on the workers' abilities. In addition, work motivation is influenced by social conditions $(50 \%)$, workers' needs $(40 \%)$, and physical conditions (10\%).

UD. King Rack is a home industry engaged in processing by producing racks. They are located on Jalan Kedinding Tengah Gang V-C Surabaya, East Java Province, Indonesia. This home industry has a workforce of 48 workers which consist of 41 male workers and 7 female workers.

This research focuses on welding workers in the rack production division. Welding rack production is the initial part of the rack manufacturing production process. The frame racks produced by the welding rack production division is the foundation of the subsequent production processes. This causes the number of frame racks produced by workers in this division to be very important for the sustainability of UD King Rack's products. However, based on the results of interviews with the workplace owner, the work productivity of workers in the welding section of the frame racks division was below standards. Based on the interviews with the workers, on average, the number of racks produced with varied shapes within 1 hour were 37 racks per day. In 8 hours of work per day, the total racks produced reaches 300. However, under certain conditions, the number of racks produced within 8 work hours per day was below the average at 200 .

The productivity of workers in the welding section of the frame racks was low because workers did not know the importance of their role and work in developing UD. King Rack and similar industries. The production of frame racks in the welding section was below the standard that should be produced by workers. This is because almost all workers in the welding section of the rack frame were elementary school graduates so their insight on the importance of work productivity was low.
Another problem faced by the workers in the welding section of the frame racks was low job satisfaction experienced. Workers did not obtain positive recognition such as praise when working well, they were unsatisfied with the lack of skills development at work due to monotonous work, and they were unsatisfied with the workplace facilities such as seating made of iron barrels with cloth pads that were uncomfortable and made them tire easily while working.

The work conditions and lack of work motivation experienced by workers made them less inclined to produce frame racks. The work was not very challenging so workers were bored with their welding work routines. Moreover, they also found it difficult to convey constraints/problems when working because there was no communication space formed by the owner of the workplace. This results in problems not being resolved and affecting work productivity. Additionally, both workers and the workplace did not target the number of racks to be welded within 8 working hours per day. The supervision by the owner of the workplace has also not been maximized. The owner's duties were limited to transferring workers to other divisions and time off work if the number of frame racks produced by each worker was below the required standard. Supervision in the form of a warning to work on time and a ban on excessive conversation when working was also not done.

According to Maurits (2010), work productivity is influenced by the workers' internal and external factors. Internal factors include education, job satisfaction, work motivation, physiological condition, skill, character, physical, salary perception, age, work experience, and work enthusiasm. Based on the explanation above, the researcher analyzed the relationship between education, job satisfaction, and work motivation with work productivity. 


\section{METHOD}

This study analyzed the relationship between education, job satisfaction, and work motivation with the work productivity of workers in the rack production welding section at UD. King Rack Surabaya, Indonesia. This was an observational study with a cross-sectional design. It used total sampling, thus the population in this study are 12 workers in the welding section of rack production.

The research began by conducting a literature review on factors that affect work productivity, instruments for measuring job satisfaction, and work motivation. Primary data was obtained through interviews to find out UD. King Rack's profile, production process, and number of racks produced every 1 hour for 8 hours of work per day. Data were also obtained through a job satisfaction questionnaire and work motivation questionnaire.

The job satisfaction variables were measured using the Minnesota satisfaction Questionnaire (MSQ) instrument. This questionnaire consists of 20 statements with five answer choices. Whereas work motivation was measured using the Stott and Walker Questionnaire (SWQ) (Wijono, 2015). This questionnaire consists of 25 statement items and also with 5 answer choices. There are 4 statements in this questionnaire which are used as "filteritems" that are not processed.

The measurement of work productivity was conducted through observation and direct interviews with workers regarding the number of frame racks produced in about 8 work hours per day. Work productivity was determined by comparing results in standard hours with input in time (Sinungan, 2008). The result would show the number of frame racks that can be produced by workers per day, while the input was the standard number of frame racks that can be made within a certain time by workers in the welding section at UD. King Rack.
The variables in this study included education, job satisfaction, work motivation, and work productivity. The data analysis was conducted by using the Spearman correlation test. This research has been approved by the Health Research Ethics Committee of Faculty of Public Health, Universitas Airlangga No.101/EA/KEPK/2019.

\section{RESULTS}

\section{Welding Section Workers' Education, Job Satisfaction, and Work Motivation}

Table 1 shows that the highest level of education of the respondents was elementary school with 7 workers $(58.3 \%)$, those who graduated from junior high were 2 workers $(16.7 \%)$, and those from senior high were 3 workers $(25 \%)$. The data showed that the majority of respondents' highest level of education was elementary school $(58.3 \%)$.

Table 1. Distribution of Respondents' Education, Job Satisfaction, and Work Motivation

\begin{tabular}{lcc}
\hline \multicolumn{1}{c}{ Variables } & N & \% \\
\hline Education Level & & \\
1. Elementary & 7 & 58.3 \\
2. Junior High & 2 & 16.7 \\
3. Senior High & 3 & 25 \\
\hline Total & 12 & 100 \\
\hline Job Satisfaction & & \\
1. Moderate & 4 & 33.3 \\
2. High & 8 & 66.7 \\
\hline Total & 12 & 100 \\
\hline Work Motivation & & \\
1. Moderate & 10 & 83.3 \\
2. High & 2 & 16.7 \\
\hline Total & 12 & 100 \\
\hline
\end{tabular}

Table 1 shows that the level of job satisfaction of the welding section workers for frame racks was high for 8 workers $(66.7 \%)$ and moderate for 4 workers $(33.3 \%)$. Thus, the majority of workers had high job satisfaction $(66.7 \%)$.

Table 1 also exhibits that for the level of work motivation of the welding 
section workers for frame racks, 10 workers $(83.3 \%)$ had a moderate level of work motivation and 2 workers $(16.7 \%)$ had high motivation. The data showed that the majority of workers had moderate work motivation $(83.3 \%)$.

\section{Welding Division Workers' Productivity}

There were 12 workers in this welding section. Below is the formula for work productivity according to Hasibuan (2010).

$$
\text { Productivity }=\frac{\text { Result }}{\text { Work Standard }}
$$

Work productivity is high if the value of productivity $(P \geq 1)$. Conversely, productivity is low if the value of productivity $(P<1)$. Below is the distribution of the respondents' work productivity:

Table 2. Respondents' Work Productivity Distribution

\begin{tabular}{lcc}
\hline Work Productivity & $\mathbf{N}$ & $\boldsymbol{\%}$ \\
\hline Low & 10 & 83.3 \\
High & 2 & 16.7 \\
\hline Total & 12 & 100 \\
\hline
\end{tabular}

Based on Table 2, the work productivity of welding section workers with low productivity are 10 workers $(83.3 \%)$ and high productivity are 2 workers $(16.7 \%)$. Therefore, the work productivity of the majority of workers was low $(83.3 \%)$.

\section{The Relationship between Education and Work Productivity on Welding Division Workers}

Maurits (2010) stated that work productivity is influenced by education. Below is the result of cross-tabulation between education and work productivity.

Table 3. Cross Tabulation of Respondents' Education and Work Productivity

\begin{tabular}{|c|c|c|c|c|c|c|}
\hline \multirow{3}{*}{$\begin{array}{l}\text { Educ } \\
\text { ation }\end{array}$} & \multicolumn{4}{|c|}{ Work Productivity } & \multirow{2}{*}{\multicolumn{2}{|c|}{ Total }} \\
\hline & \multicolumn{2}{|c|}{ Low } & \multicolumn{2}{|c|}{ High } & & \\
\hline & $\mathbf{n}$ & $\%$ & n & $\%$ & $\mathbf{n}$ & $\%$ \\
\hline $\begin{array}{l}\text { Elem } \\
\text { entar } \\
\mathrm{y}\end{array}$ & 7 & 100 & 0 & 0 & 7 & $\begin{array}{r}10 \\
0\end{array}$ \\
\hline $\begin{array}{l}\text { Junio } \\
\mathrm{r} \\
\text { High }\end{array}$ & 1 & 50 & 1 & 50 & 2 & $\begin{array}{r}10 \\
0\end{array}$ \\
\hline $\begin{array}{l}\text { Senio } \\
\mathrm{r} \\
\text { High }\end{array}$ & 2 & 66.7 & 1 & 33.3 & 3 & $\begin{array}{r}10 \\
0\end{array}$ \\
\hline Total & 10 & 83.3 & 2 & 16.7 & 12 & $\begin{array}{r}10 \\
0\end{array}$ \\
\hline
\end{tabular}

Table 3 exhibits that the productivity of workers with elementary level education was low with 7 workers $(100 \%)$. Workers with a junior high level of education also had a low productivity with 1 worker (50\%) and high productivity with 1 worker $(50 \%)$. And workers with a senior high level of education had low productivity with 2 workers $(66.7 \%)$ and high productivity with 1 worker $(33.3 \%)$.

The majority of workers' highest level of education was elementary school and the productivity was low. Based on the correlation test, the correlation coefficient value $=0.475$ which means the level of the relationship between education and work productivity is moderate.

\section{The Relationship Between Job Satisfaction and Work Productivity on Welding Division Workers}

Maurits (2010) stated that work productivity is influenced by job satisfaction. Below is a cross tabulation between job satisfaction and work productivity.

Table 4. Cross Tabulation of Respondents' Job Satisfaction and Work Productivity 


\begin{tabular}{|c|c|c|c|c|c|c|}
\hline \multirow{3}{*}{$\begin{array}{c}\text { Job } \\
\text { Satisfa } \\
\text { ction }\end{array}$} & \multicolumn{4}{|c|}{$\begin{array}{c}\text { Work } \\
\text { Productivity }\end{array}$} & \multirow{2}{*}{\multicolumn{2}{|c|}{ Total }} \\
\hline & \multicolumn{2}{|c|}{ Low } & \multicolumn{2}{|c|}{$\underset{\text { hig }}{\text { Hig }}$} & & \\
\hline & $\mathbf{n}$ & $\%$ & $\mathbf{n}$ & \% & $\mathbf{n}$ & $\%$ \\
\hline $\begin{array}{l}\text { Modera } \\
\text { te }\end{array}$ & 4 & 100 & 0 & 0 & 4 & 100 \\
\hline High & 6 & 75 & 2 & $\begin{array}{l}2 \\
5\end{array}$ & 8 & 100 \\
\hline Total & 10 & 83.3 & 2 & $\begin{array}{l}1 \\
6\end{array}$ & 12 & 100 \\
\hline
\end{tabular}

Table 4 shows that workers with moderate job satisfaction and low productivity were 4 workers $(100 \%)$. Whereas workers that had high job satisfaction and low productivity were 6 workers (75\%) and high job satisfaction and productivity were 2 workers $(25 \%)$.

The majority of workers had high job satisfaction but low productivity. Based on the correlation test, the correlation coefficient value $=0.316$, which means the level of the relationship between education and work productivity is low.

\section{The Relationship Between Work Motivation and Work Productivity on Welding Division Workers}

Maurits (2010) stated that work productivity is influenced by work motivation. Below is a cross tabulation between work motivation and work productivity.

Table 5. Cross Tabulation of Respondents' Work Motivation and Work Productivity

\begin{tabular}{|c|c|c|c|c|c|c|}
\hline \multirow{3}{*}{$\begin{array}{c}\text { Work } \\
\text { Motiva } \\
\text { tion }\end{array}$} & \multicolumn{4}{|c|}{ Work Productivity } & \multirow{2}{*}{\multicolumn{2}{|c|}{ Total }} \\
\hline & \multicolumn{2}{|c|}{ Low } & \multicolumn{2}{|c|}{ High } & & \\
\hline & $\mathbf{n}$ & $\%$ & $\mathbf{n}$ & $\%$ & $\mathbf{n}$ & $\%$ \\
\hline $\begin{array}{l}\text { Modera } \\
\text { te }\end{array}$ & 10 & 100 & 0 & 0 & 10 & 100 \\
\hline High & 0 & 0 & 2 & 100 & 2 & 100 \\
\hline Total & 10 & 83.3 & 2 & 16.7 & 12 & 100 \\
\hline
\end{tabular}

of workers with moderate work motivation and low productivity were 10 workers $(100 \%)$. And workers with high work motivation and high productivity were 2 workers $(100 \%)$. The majority of workers had moderate work motivation and low work productivity. Based on the correlation test the correlation coefficient value $=1.000$ which means that the relationship between motivation and work productivity is very strong.

\section{DISCUSSION}

Work productivity is a performance result that considers the output and input used by the company over a certain time (Sunyoto, 2012). This means that productivity is a form of comparison between results and all of the resources utilized to create those results. The majority workers in the welding had low productivity. The worker productivity of the welding section was below the work standard of what is able to be produced. Workers did not have a target number of shelf frames that must be produced within 8 work hours per day. This condition resulted in the workers to not have the desire to reach the number of frame racks that should be produced. Moreover, the owner of UD. King Rack has also not determined the number of frame racks that must be produced by each worker within 8 work hours per day. The absence of a good target planning system among UD. King Rack owners and workers resulted in the substandard number of frame racks produced per day. The other main variable that causes low work productivity was the low work motivation possessed by workers. Additionally, the variable level of education also has a relationship with the work productivity of workers in the welding section of UD. King Rack.

Education is important for everyone, if a person has a high education, both formal and informal, then they will have a broad insight of the world. This insight raises awareness about the importance of work productivity. After 
realizing the importance of work productivity, a person will be encouraged to take productive actions (Sedarmayanti, 2011)

Based on the results of the education correlation test related to work productivity, the majority of workers with low productivity were elementary school graduates. Respondents that were elementary school graduates had substandard production outputs. They have limited insight so their awareness of the importance of productivity was low. This limited insight has caused workers not encouraged these workers to take productive actions. In turn, this has caused the sub-standard number of shelves produced that did not meet productivity expectations.

This result is in line with the research conducted by Hermanto (2014), he stated that education influences work productivity. Another study by Muhibin (2018) also stated that education affects workers' performance. Moreover, in Handayani's (2014) study, employees' education levels also affected their performance in selling fertilizer in $\mathrm{CV}$ Pandan Wangi. Similar results were also stated by Arisandara (2016), who found that education influences worker performance in PT. BPR Nusamba. In addition, Iskandar (2018) also stated that the higher a worker's education, the higher their performance.

Research has also been conducted by Hidayat and Budiatma (2018) who found that education has influenced job performance. Similar results were also seen by Ishola and Abdulrahamon (2018) and (Bharamagoudar and Angadi, 2019) who stated that education is positively and significantly related with the job performance of workers. This implies that a higher of education will increase job performance. Workers with higher education have greater opportunities to acquire and retain more information in the workplace and in turn perform better too.

Job satisfaction is also an important aspect of the job. Job satisfaction is the employee's attitude towards work which includes work situations, cooperation, and rewards received by employees (Sutrisno, 2010). Workers who have job satisfaction will tend to not complain, rarely skip work, and be disciplined in doing their work. This also makes workers productive when working (Wijono, 2015).

According to Sutrisno (2010), job satisfaction is the result of when an employee assesses their pleasant and unpleasant emotion states regarding work. This satisfaction reflects a positive attitude at work. Job satisfaction is individual, which is meaning that each individual has a different level of job satisfaction in accordance with the values that apply to him. Everyone has different desires. The more aspects of the work that follow the wishes of workers, the higher the level of satisfaction felt by them.

Opportunities to advance, security at work, salary, company and management, supervision, intrinsic work factors, working conditions, social aspects of work, communication, and facilities are factors that can affect one's job satisfaction (Sutrisno, 2010). Based on the results of the job satisfaction test, we found that job satisfaction is not related to work productivity. The majority of workers in the welding section of UD. King Rack had high job satisfaction, but low work productivity. This was because the workers felt satisfied with receiving salaries that follow the number of shelf frames produced. Moreover, the bonus they receive if the number of frame racks produced are above average also made the workers feel satisfied. Another factor that makes workers satisfied was the fact that they were given the freedom to count the number of frame racks. Each worker reported the number of frame racks produced to the supervisor.

Workers in the welding section of the frame rack formation at UD. King Rack were satisfied with the business they have while working. The welding job of forming frame racks was the second stage of the UD. 
King Rack production process. This condition made workers to always work non-stop. Workers that were busy producing more shelves also received higher salaries. The welding section workers at UD. King Rack were also satisfied with the relationships with their fellow colleagues. This was because workers would help each other if there is an increase in order of racks needed. Workers were allowed to assist other workers in welding the formation of the frame racks. This condition made the workload received by workers not too heavy. Moreover, the commitment held by the workplace owner in ensuring the continuity of work also made the workers feel satisfied. The workplace owner created commitments with prospective workers, they stated to prospective workers who want to work at UD. King Rack Surabaya, that they must be earnest in their work. Workers who are not serious about working will be terminated or be moved to other division of the production process by the owner of UD. King Rack.

The various conditions above attributed to the high job satisfaction possessed by the welding section workers. However, even though the workers have a high job satisfaction, work productivity in producing the number of frame racks was still below the standard number that should be produced by workers. This was because job satisfaction is not enough to make workers increase the number of frame racks produced. Workers must also obtain support from the workplace owner, this could be in the form of direct or indirect praise to workers who have produced an appropriate or even above standard number of frame racks.

This result is in line with other studies which state that job satisfaction does not have a significant effect on work productivity (Muayyad and Gawi, 2016). According to Maswani, Rahmat and Rina (2019), job satisfaction has a negative influence on workers performance. In addition, Pawirosumarto, Sarjana and
Gunawan (2017) also stated that job satisfaction also does not influence job performance.

This result also in line with other studies which stated that job satisfaction does not influence the job performance of service workers on McConnell Dowell Services Company (Parlaungan and Ramadhan, 2019). Similar research results were also found by Kulachai et al., (2018), Putri (2018), and Husein and Hanifah (2019) who stated that job satisfaction did not significantly influence job performance.

According to Hasibuan (2010), motivation comes from the latin word movere which means encouragement or move. Motivation is a form of encouragement given to humans to mobilize their potential to work together productively and achieve goals. Motivation can also be said as a desire found in individuals that stimulates them to conduct an action (Hasibuan, 2010).

The correlation test of this study shows that work motivation is related to work productivity. The majority of the welding section workers had low motivation and productivity. This is because the majority of workers have no desire to improve their work performance. This condition can be seen from the low levels of responsibility at work. The lack of responsibility at work can be seen from the number of delays. The work hours at UD King Rack is 7:30 a.m, however the workers did not immediately start working. The majority of workers started working at 08.00. This causes below standard productivity. As a result, workers could not meet work output standards that should be achievable and have low work productivity.

The workers in the welding section of rack production at UD. King Rack had moderate work motivation because they do not have desire to be center of attention in the workplace. The workers did not want to stand out or look different compared to other workers. The result is that workers do not try to use the best of their abilities to produce frame racks that are above 
standard. Moreover, they had low work motivation because they felt hesitant to be firm with other workers. If there are workers who produce frame racks below the standard number, then other workers felt no responsibility for the workers who produce below the standard number of frame racks. Additionally, the workers in this study felt uncertain in designing work targets. This is because the owner of UD. King Rack has not determined the exact number of frame racks each worker must produce withing 8 work hours per day. This condition made the workers to not design a daily work target for the number of frame racks that must be produced.

The workers also did not have the desire to lead the group. This is because the welding work consists individual work so no collaboration was needed to produce a rack frame. However, if the number of certain rack orders increases, some workers will work on the same framework. In addition, welding workers also do not have desire to control others. This causes workers to not be able to remind other workers who have low work productivity. This is also related to the fact that the workers tend to avoid conflict about how to do the job. The workers have the freedom to use their own method for welding the rack frame. This results in workers not having opportunity to direct other workers who use welding methods may be less efficient.

There was also a feeling of uncertainty felt by the workers to ask for help from others when there are problems. This causes workers to not be able to express their difficulties in welding the formation of the rack frame. If workers felt difficulties at work, then it can affect the number of frame racks produced. The workers also felt uncertain to show the best performance in the team. This causes workers to not be able to produce frame racks in accordance with expectations. In addition, workers also felt uncertain to talk to large groups. This causes the workers to be unable to express the difficulties experienced while working.

Furthermore, workers in welding section of UD. King Rack felt bored with the work in the welding section of the shelf frame. This is because of the monotonous working conditions. The process of welding for the formation of frame racks consists of workers placing pieces of iron above the frame rack model. Then, the worker's left foot would step on the welding pedal and both hands of the worker would hold a frame rack model. The frame rack model would then be moved to place the welding tip directly above the piece of iron to be joined. This process would be repeated continuously for other frame racks.

The results of this study is in line with other research that found work motivation to be related to work productivity (Ardiansyah Barry and Sunardi, 2008; Reigion, Umi and Santoso Adi, 2019). These studies stated that workers' productivity would decrease due to low work motivation. Moreover, the productivity of cooperative employees was positively and significantly affected by work motivation. This means that if work motivation is increased, employee productivity will also increase. According to (Laminia and Muniroh, 2015) work motivation is related to work productivity in Home Industry X Surabaya. Another study conducted by Sabena and Harahap (2016) also stated that the higher the work motivation possessed by workers, the higher the work productivity. Similar research results were also found by Faslah and Savitri (2013) and Resnawa, Prana and Wahyudi (2015) who found that work motivation provides an influence on work productivity.

Finally, this study's results are also in line with the research conducted by Jauhari and Ripki (2019) and Gunawan and Sondakh, (2019) who stated that there is a positive relationship between work motivation and performance. This means that the higher the workers' job satisfaction, the higher their work performance. Similar 
studies have found that highly motivated of workers would have improved performance (Husniyawati and Wulandari, 2016). Other studies have also found that workers with high work motivation would have good work performances (Tampubolon, 2016; Habba et al., 2017; Mansyur et al., 2017). In addition, work motivation affecting work performance was also stated by (Mubarok, 2019).

\section{CONCLUSION}

This research showed that the majority of respondents graduated from elementary school and had high job satisfaction. Their work motivation was moderate and a majority of the respondents' work productivity were low.

This study found that there is a relationship education and productivity in workers in the welding section of rack production at UD. King Rack. There is no relationship between job satisfaction and productivity and there is a relationship between motivation and productivity in workers in the welding section of rack production at UD. King Rack.

The results of this study suggest that the owner of UD. King Rack needs to consider the education level of prospective employees. This aims to ensure that workers have insight into the importance of increasing productivity. Additionally, it is necessary to increase work motivation directly and indirectly. Direct motivation can be done by the owner giving praise and appreciation to the workers who can produce racks above the work standard. Moreover, work motivation can be increased indirectly by improving work facilities. The work facilities that need to be improved are work seats and frame rack arrangement.

The owner of UD. King Rack could also encourage their workers' motivation by providing bonuses if the worker shows their best ability to produce frame racks above the expected standard. In addition, the owner should encourage their workers' motivation by conducting daily rotations in the type of shelf frames that must be done by each worker so that workers do not feel bored.

It is also recommended for UD. King Rack to increase their workers' motivation. Work motivation can be increased through setting a daily target for the number of frame racks to be produced. The determination of daily targets would make the workers feel motivated in improving their performance and increase their sense of responsibility at work. Therefore, the owner of UD. King Rack can remind workers to produce shelf frames above the expected productivity standards. Also, work motivation can also be increased by the owner notifying workers about how to weld effective frame racks. This is done so the number of frame racks produced will achieve the expected standards.

Increased work productivity can be done by maintaining good relations between employees. It is necessary to create a comfortable working atmosphere for workers, one of which is by creating open communication relationships between workers to discuss constraints in the workplace and strategies that can increase worker productivity in producing shelf frameworks.

\section{REFERENCES}

Ardiansyah Barry , Sunardi, S. B. (2008) 'Analisis Hubungan Motivasi Kerja, Kepuasan Kerja, Pengalaman Kerja, Keselamatan Kerja dan Kesehatan dengan Produktivitas Karyawan dengan Menggunakan Metode Regresi Linear Berganda (Stusi Kasus di PT. Indonesia Multi colour printing)', Strategic (Jurnal Pendidikan Manajemen Bisnis), 7(September), pp. 1-15. doi: 10.33005/tekmapro.v14i1.28.

Arisandara, M. L. (2016) 'Pengaruh Tingkat Pendidikan, Keterampilan Kerja dan Sikap Kerja Karyawan 
Terhadap Prestasi Kerja Karyawan PT. BPR Nusamba Brondong Lamongan', Ekonomi Fakultas Kadiri, 1(2), pp. 103-116. doi: 10.30737/ekonika.v1i2.10.

Asian Development Bank (2018) Indonesia: Enhancing Productivity through Quality Jobs. doi: 10.22617/TCS189213-2.

Bharamagoudar, M. V and Angadi, J. G. (2019) 'Impact Analysis of Education Level for Job Perception and Job Performance of PDOs in Karnataka State , India', International Journal of Current Microbiology and Applied Sciences, 8(01), pp. 3154-3161. doi: 10.20546/ijcmas.2019.801.337.

Faslah, R. and Savitri, M. T. (2013) 'Pengaruh Motivasi Kerja Dan Disiplin Kerja Terhadap Produktivitas Kerja Pada Karyawan PT. KABELINDO MURNI, Tbk.', Pendidikan Ekonomi dan Bisnis (JPEB), 1(2), pp. 40-53. doi: 10.21009/jpeb.001.2.3.

Gunawan, H. M. and Sondakh, O. (2019) 'The Impact of Work Motivation, Work Engagement, and Job Satisfaction Toward Job Performance in PT . XYZ Surabaya', Europan Journal of Business and Management, 11(20), pp. 48-56. doi: 10.7176/EJBM.

Habba, D. et al. (2017) 'The Effect of Leadership, Organisational Culture and Work Motivation on Job Satisfaction and Job Performance among Civil Servants in Maros District Technical Working Unit', IRA-International Journal of Management \& Social Sciences, 07(01), pp. 52-64. doi: 10.31227/osf.io/rvmgy.

Handayani, N. T. (2014) 'Pengaruh Tingkat Pendidikan Karyawan Terhadap Penjualan Pupuk Pada CV. Pandan Wangi Kab. Madiun', EQUILIBRIUM, 2(2), pp. 199-221. doi: 10.25273/equilibrium.v2i2.648.

Hasibuan, M. (2010) Manajemen Sumberdaya Manusia. Jakarta: Bumi Aksara.

Hermanto, B. (2014) 'Pengaruh Pendidikan Dan Pelatihan Terhadap Produktivitas Kerja Karyawan Pada PT. PLN (Persero) UPJ AMBUTEN', Performance Bisnis \& Akuntansi, IV(1), pp. 31-38. doi: 10.24929/feb.v4i1.78.

Hidayat, R. and Budiatma, J. (2018) 'Education and Job Training on Employee Performance', International Journal of Social Sciences and Humanities, 2(2). doi: 10.29332/ijssh.v2n1.140.

Husein, N. M. and Hanifah (2019) 'The Effect of Job Satisfaction on Employee Performance Through Coaching as Intervening Variables in Banjarmasin Government', Advance In Economics, Business and Management Research, 64, pp. 830-836. doi: 10.2991/piceeba218.2019.72.

Husniyawati, Y. R. and Wulandari, R. D. (2016) 'Analisis Motivasi Terhadap Kinerja Kader Posyandu Berdasarkan Teori Victor Vroom', Jurnal Administrasi Kesehatan Indonesia (JAKI), 4(2), pp. 126135. doi: 10.20473/jaki.v4i2.2016.126-135.

Ishola and Abdulrahamon, A. (2018) 'Impact of Educational , Professional Qualification and Years of Experience on Accountant s ' Job Performance', Journal of Accounting and Financial Management, 4(1), pp. 32-44. doi: 10.5281/zenodo.1210796.

Iskandar, Y. (2018) 'Analisis Pemberian Insentif Dan Tingkat Pendidikan Terhadap Kinerja Karyawan Pada PT. Mega Finance Cabang Rengat Kabupaten Indragiri Hulu', Manajemen Bisnis, VII(03), pp. 7686. doi: 10.34006/jmb.v7i3.16.

Jauhari, A. and Ripki, H. (2019) 
'Relationship between Motivation and Job Satisfaction with Performance', in International Conference on Technology and Educational Science. Bali. doi: 10.4108/eai.21-11-2018.2282199.

Kulachai, W. et al. (2018) 'Internal communication, employee participation, job satisfaction, and employee performance', Advances in Social Science, Education and Humanities Research (ASSEHR), 186(Insyma), pp. 124-128. doi: 10.2991/insyma-18.2018.31.

Laminia, D. and Muniroh, L. (2015) 'Hubungan Motivasi dan Masa Kerja dengan Produktivitas Pekerja di Home Industry', The Indonesian Journal of Occupational Safety and Health (IJOSH), 7(2), pp. 241-248. doi:

10.20473/IJOSH.V7I2.2018.240248.

Mansyur, L. et al. (2017) 'An Examination of the Mediating Role of Employees ' Job Satisfaction on the Relations between the Work Motivation, Leadership Style, Competence and Employees ' Performance', IRAInternational Journal of Management \& Social Sciences, 07(02), pp. 232-243. doi: 10.21013/jmss.v7.n2.p13.

Maswani, Rahmat, S. T. Y. and Rina, A. (2019) 'The Relationship Between Organizational Culture And Job Satisfaction Towards Organizational Commitment And Employee Performance', Russian Journal of Agricultural and SocioEconomic Sciences (RJOAS), 4(88), pp. 144-152. doi: 10.18551/rjoas.2019-04.19.

Maurits, L. S. K. (2010) Sekilas Tentang Kelelahan Kerja. Yogyakarta: Amara Book.

Muayyad, D. M. and Gawi, A. I. O. (2016) 'Pengaruh Kepuasan Kerja Terhadap Produktivitas Kerja Pegawai Bank Syariah X Kantor
Wilayah II', Manajemen dan Pemasaran Jasa, 9(1), p. 24. doi: https://doi.org/10.25105/jmpj.v9i1. 1396.

Mubarok, E. S. (2019) 'The Influence of Training, Motivation, and Work Ethics on the Internal Communication and Their Impact on the Employee Performance', 11(24), pp. 86-93. doi: 10.7176/EJBM.

Muhibin, S. M. (2018) 'Pengaruh Pendidikan Dan Pelatihan Serta Motivasi Kerja Terhadap Kinerja Karyawan PT. Asuransi Jasa Indonesia (PERSERO)', Manajemen Bisnis Krisnadwipayana, 6(2). doi: 10.35137/jmbk.v6i2.188.

Parlaungan, A. N. and Ramadhan, D. A. (2019) 'Effect Of Country of Origin Employee, Work Discipline And Job Satisfaction On EMployee Performance In McConnel Dowell Company Service Batam Indonesia', SocArXiv, pp. 1-13. doi: 10.31235/osf.io/wp8bz.

Pawirosumarto, S., Sarjana, P. K. and Gunawan, R. (2017) 'The Effect of Work Environment , Leadership Style, and Organizational Culture Towards Job Satisfaction and Its Implication Towards Employee Performance in Parador Hotels and Resort, Indonesia', International Journal of Law and Management, 59(6), pp. 1337-1358. doi: 10.1108/IJLMA-10-2016-0085.

Putri, R. A. (2018) 'Leadership Style and Interpersonal Communication of Employee Satisfaction a nd It' $\mathrm{s}$ Effect on The Employee Performance', Jurnal Pendidikan Bisnis dan Manajemen, 4(3), pp. 101-106. doi: 10.17977/um003v4i32018p108.

Reigion, J., Umi, F. and Santoso Adi (2019) 'Pengaruh Kompetensi, Motivasi Kerja, Beban Kerja, Dan Pelatihan Terhadap Produktivitas Kerja 
Sumber Daya Manusia Koperasi Serba Usaha Anak Mandiri Ponorogo', ISQUANT (Jurnal Ekonomi Manajemen \& Akuntansi), 3(1). doi: 10.24269/iso.v3i1.244.

Resnawa, S., Prana, R. R. and Wahyudi, D. (2015) 'Pengaruh Motivasi Dan Disiplin Terhadap Produktivitas Kerja Karyawan Di PT. RUBYCON Indonesia', Pendidikan Ekonomi Dan Bisnis (JPEB), 1(A2), pp. 1-10. doi: 10.31227/osf.io/tjh9a.

Sabena, A. and Harahap, R. H. (2016) 'Pengaruh Motivasi Kerja dan Kepuasan Kerja terhadap Peningkatan Produktivitas Kerja Karyawan', Administrasi Publik, 6(2), pp. 137-146. doi: 10.31289/jap.v6i2.1329.

Sastrohadiwiryo, B. S. (2005) Manajemen Tenaga Kerja Indonesia. Jakarta: Bumi Aksara.
Sedarmayanti (2011) Tata Cara dan Produktivitas Kerja. Jakarta: Bumi Aksara.

Sinungan, M. (2008) Produktivitas Apa dan Bagaimana. Jakarta: Bumi Aksara.

Sunyoto, D. (2012) Manajemen Sumberdaya Manusia. Yogyakarta: CAPS / Center Of Academic Publishing Service.

Sutrisno, E. (2010) Manajemen Sumberdaya Manusia. Jakarta: Prenada Media Group.

Tampubolon, H. (2016) 'The Relationship Between Employee Engagement, Job Motivation, and Job Satisfaction Towards The Employee Performance', Corporate Ownership \& Control, 13(2), pp. 473-477. doi: 10.22495/cocv13i2c2p9.

Wijono, S. (2015) Psikologi Industri dan Organisasi. Revisi. Jakarta: Kencana Prenada Media Group. 